\title{
Red cells distribution width after cardiac arrest
}

\author{
V Fontana*, P Villois, C Righy Shinotsuka, L Nobile, J-L Vincent, J Creteur, FS Taccone \\ From ESICM LIVES 2015 \\ Berlin, Germany. 3-7 October 2015
}

\section{Intr}

Red cell distribution width (RDW) is a quantitative measure of the variability in size of erythrocytes and it is used for the differential diagnosis of anemia. Moreover, in critically ill patients, high RDW values have been associated with increased hospital mortality. No data on the impact of RDW on the outcome of patients resuscitated from cardiac arrest (CA) are available.

\section{Objectives}

To investigate whether RDW values are associated with outcome after CA.

\section{Methods}

Retrospective analysis of an institutional database including all adult comatose patients admitted to the Intensive Care Unit (ICU) after CA from January 2007 to December 2014. Inclusion criteria were as follows: age $\geq 18$, non-traumatic arrest and survival $\geq 24$ hours after admission. We collected demographics and CA related data. We also collected daily routine blood analyses; RDW (normal values: 10.9-13.4\%), was obtained from the day of admission to day 3 . We recorded ICU mortality and long-term neurological outcome; a CPC score of 3-5 at 3-months was used to define poor neurological outcome (PNO).

\section{Results}

Of the 404 eligible patients, 14 were excluded because of lack of blood analyses and 390 were eventually included. Median age was 62 [52-75] years and 275 (70\%) were male. Median time to ROSC was 15 [8-25] minutes and $241(62 \%)$ patients had a non-shockable initial rhythm. ICU mortality was $56 \%(\mathrm{n}=220)$ and 3-month PNO was observed in 251 (64\%) patients. Median RDW on the day of admission was 14 [13.0-15.2]\% and remained stable over the observation period. RDW on admission was within normal ranges in 145 (37\%) patients. We found a

Erasme University Hospital, Bruxelles, Belgium significantly higher RDW on admission in non-survivors than survivors (14.2 [13.2-15.5]\% vs. 13.7 [12.6-14.9]\%; $\mathrm{p}=0.0007)$ as well as in patients with PNO when compared to those with favourable outcome (14.2 [13.1-15.5]\% vs. 13.6 [12.6-14.8]\%; $\mathrm{p}=0.001)$. ICU mortality increased with increasing RDW quartiles (from $42 \%$ for RDW $\leq 12.9 \%$ [Quartile I] to $65 \%$ for RDW $\geq 15.6 \%$ [Quartile IV]; $\mathrm{p}=0.001$ ) as well as PNO (from $51 \%$ to $72 \%$ for the same RDW ranges; $\mathrm{p}=0.003)$.

\section{Conclusions}

RDW values are higher in non-survivors and patients with poor neurological outcome after CA. Patients with the highest RDW values will have a higher mortality rate and worse neurological recovery.

Published: 1 October 2015

doi:10.1186/2197-425X-3-S1-A202

Cite this article as: Fontana et al:: Red cells distribution width after cardiac arrest. Intensive Care Medicine Experimental 2015 3(Suppl 1):A202.

Submit your manuscript to a SpringerOpen ${ }^{\circ}$ journal and benefit from:

- Convenient online submission

- Rigorous peer review

- Immediate publication on acceptance

- Open access: articles freely available online

- High visibility within the field

- Retaining the copyright to your article

Submit your next manuscript at $\gg$ springeropen.com (c) 2015 Fontana et al.; This is an Open Access article distributed under the terms of the Creative Commons Attribution License (http:// creativecommons.org/licenses/by/4.0), which permits unrestricted use, distribution, and reproduction in any medium, provided the original work is properly cited. 